UDC 930

\title{
OUTSTANDING GRADUATE OF THE CRIMEAN UNIVERSITY - PROFESSOR A. MAZHBITS
}

\author{
A. Andreeva, A.Zolotova, G. Samburov \\ Northern State Medical University. Arkhangelsk, Russian Federation \\ museumnsmu@mail.ru
}

\begin{abstract}
Notable alumni of the Crimean University, an obstetrician-gynecologist, urologist, Doctor of Medical Sciences, Professor Alexander Mazhbits made a great contribution to the history of medicine of the USSR, being the author of over 120 scientific works and 7 books, many scientific inventions and publications on obstetric and gynecological urology and its history, he was a creator of the textbook "Operative urogynecology", inventor and prominent scientist. Scientific activity Mazhbits began in 1925 in the Leningrad Research Institute of Obstetrics and Gynecology, where he worked almost all his life. During summers A.M. Mazhbits was a gynecologist at the resorts of Crimea, consultant gynecologist of the resort of Sochi-Matsesta and consisted in commissions for the selection of gynecological patients. During the Great Patriotic War LieutenantColonel of the Medical Service of the USSR A. Mazhbits made an important contribution to the health of the wounded and sick women, was the main army gynecologist of the air defense forces of the Leningrad Military District. Professor A. Mazhbits within 1953-1959 worked in the Arkhangelsk State Medical Institute (now - the North-State Medical University), where he retained his personal business, thanks to which it was possible to establish little-known facts of his biography.
\end{abstract}

Keywords: urology, gynecology, balneotherapy, Crimean university.

Mazhbits Alexander Moiseevich (Abraham Haim Shliom Movshevich) was born on 4 November (21 November on new style) 1894 in the village Gorodok (Victoria station) of Kamenetz-Podolsk province in the family of non-manual workers. In the questionnaire Alexander Mazhbits was always pointed out the origin and his nationality as a Jew, in this connection pointed out that he had a number of difficulties, which are then traced in his biography. In 1916 he graduated from high school in Odessa. In the same year he entered the faculty of basic psycho-neurological institute in St. Petersburg, where in 1918 he was transferred to the Crimean University for the 2 nd year of medical school. After graduating from the Medical Faculty of the University of Crimea (at present - Tavricheskaya Academy of Crimean Federal University named by V.I. Vernadsky) in 1922 Alexander Mazhbits started working as an intern in obstetric clinic in Simferopol Crimean University, led by Professor Petr Georgievich Bondarev, led classes with students in obstetrics.

The scientific activity A.M. Mazhbits began in 1925 at the Leningrad Research Institute of obstetrics and gynecology, where he worked first supernumerary intern, then junior and senior assistant, assistant professor, and from 1937 to 1949 - Professor, MD as Head of the urogynecological clinic at the institute. In 1929-1949 years he led sessions with doctors at Postgraduate Medical Institute for operative gynecology, obstetrics for operational, the female gonorrhea and obstetric gynecological urology. At the same time he headed the clinic at the National Research Institute of dermatology and venereal. Along with his work at the clinic, he was a gynecologist consultan att medical commissions of Smolny, Volodarsky dispensary "Textilschik", First Utility hospitals and others. In the summer time, from 1921 to 1940, and again in 1946-1947 he worked as a gynecologist in the resorts of Balaklava,Yalta, Chokrak mud baths (Kerch Peninsula), Saki mud baths, Maynakskaya mud baths (Yevpatoriya) Essentukskaya mud baths, and consisted in the committees for the 
selection of gynecologic patients of Caucasian Mineral Waters, clinic in Zheleznovodsk, and in subsequent years he was a gynecologist consultant at resort of Sochi-Matsesta.

In 1936, under his guidance the book "Obstetric and gynecological urology with the atlas" was published. It was the first monograph on the diseases of the women genitourinary system, the discussion regarding changes in the urinary system in the different stages of pregnancy, during and after childbirth, semiotics and diagnostics urogynaecological diseases, conservative and some operative methods of treatment. The book aroused great interest, and has been recognized and praised by the leading specialists in this field. In June 1941, shortly after the outbreak of war, it began deployment of a strong women's surgical hospital for 630 beds at the Institute. 5 branches were established, the chiefs of which, together with Prof. A.M. Mazhbits, were appointed officers of the Institute like Senior Researcher L.A. Shuster, professor R.G. Lurie, assistant professor E. Gurevich, MD N.N. Cuba and Professor L.M. Bublichenko. During the Great Patriotic War from 1941 to 1943 A.M. Mazhbits was head surgeon of evacuation hospital 1448, a senior surgeon and gynecologist of the hospital for the lightly wounded 4171 of the Leningrad Front, and from May 1943 until the end of the war he was the army chief gynecologist of air defense troops of the Leningrad Military District.

As head surgeon of evacuation hospitals, A.M. Mazhbits produced numerous doctors, conducted theoretical and practical training, clinical and pathological-anatomical conference. In 1943-1946 years he had trained a group of military gynecologists to serve the female contingent of the army of the Leningrad Front; him conducted a systematic assemblies of physicians, military paramedics and health inspectors. He was chairman of the Military-medical commission. In wartime, his research and writings have been devoted to new techniques in obstetrics and gynecology, the effects of birth trauma and create a new urethra in women injured. He developed methods of acquisition contingent of troops of women and health measures for them, paid attention to their outfit and the course of pregnancy, the impact of military service on the health of women soldiers and their treatment of occupational diseases. For his work during the war, he was awarded several state awards: the Order of the Patriotic War II degree, medals "For the Defense of Leningrad" and "For Victory over Germany in the Great Patriotic War of 1941-1945". He was demobilized in 1946 with the rank of lieutenant colonel of medical service.

After demobilization he was appointed as head of the Central Institute urogynecological Clinic of Obstetrics and Gynecology (TSIAG) of the USSR Ministry of Health until the liquidation by the decision of the Presidium of the USSR Academy of Medical Sciences Institute urogynecological office in 1949. From 1945 to 1952 he was the chairman of the Leningrad section of the obstetric and gynecological society of female gonorrhea, he was also a member of the board of committee of maternity of the Leningrad City Healthcare Department. Already in 1921 Alexander Mazhbits worked on conservative gynecology and balneotherapy, being a gynecologist consultant of Russian resorts during the summertime. He wrote about the benefits of pelvic massage in combination with physical therapy, spa water and mud therapy. In 1947, the Central Institute of Obstetrics and Gynecology of the USSR Ministry of Health in the Leningrad released its guide for physicians "Balneotherapy in gynecology and obstetrics". In the same year another work was published - "Bibliography of scientific works of the Central Institute of Obstetrics and Gynecology in 150 years (1797-1947)". He wrote that the pelvic massage in combination with physical therapy, spa water and mud therapy works physiologically, and is a strong irritant of tissue.

Helping the Soviet Public Health Department A.M. Mazhbits traveled to the cities and regions of the USSR: Sochi, Kaliningrad, Chelyabinsk, Murmansk, Molotov, Pskov, Tallinn and others, where he conducted a survey of obstetric and gynecological institutions 
and dermatovenereological network, instructed and trained the doctors. In 1953, Alexander Moiseevich was sent to work in the Arkhangelsk State Medical Institute (ASMI, at present - Northern State Medical University, NSMU). It is noteworthy that from 1934 to 1944 the department has successfully led a well-known representative of the scientific school of D.O. Ott by professor V.V. Preobrazhensky, after whose death managers are constantly changed in a clinic.

In 1950-s Professor A.M. Mazhbits was already well-known scientist who published over a hundred scientific works on issues of urology, operative gynecology, plastic surgery of the pelvic organs. The arrival of the head with such an authoritative name and with a big practical experience foreshadowed the Department of Obstetrics and Gynecology of ASMI flourishing scientific activity. Under his guidance, the two volumes of scientific papers have been published. A.M. Mazhbits conducted the balneological researching at the health resorts of the European North (Solvychegodsk, Kotlas), developing new methods of treatment using pelvic massage in combination with physical therapy, spa water and mud therapy at various women's diseases, counseling patients, etc. He had developed a number of unique surgical interventions ("A Mazhbits Operation") in the treatment of urinary incontinence in women with prolapse of the uterus and vagina, with injuries and fistula urinary tract in women, and others. To his surgical treatment visited patients from different cities and villages of Russia. A.M. Mazhbits was the author of the inventions, including a new model of a spoon to capture the discharge of the genitourinary system in women, beautiful practices in matters of urology and gynecology, developed a number of unique surgical interventions in the treatment of urinary incontinence in women, she has developed a number of new methods for the treatment of various forms of women's gonorrhea. As a result of the previously gained experience and new studies at Arkhangelsk in 1957 he released the book "Women's Gonorrhea and its complications."

Alexander Moiseevich conducted the student scientific club at the department of urology and gynecology of ASMI and served as scientific director of the course of secondary vocational education institution, he participated in meetings with the teachers in student dormitories - Professor AM Mazhbits spoke of "Pushkin's Petersburg". Since 1953 he was chairman of the Scientific Society of Obstetrics and Gynecology in Arkhangelsk. In 1958 was dismissed from his post, and in 1959 resigned from the ASMI and returned to Leningrad. In 1960, Professor A.M. Mazhbits headed the newly opened department of obstetrics and gynecology at the Novokuznetsk State Institute of Advanced Medical Education (NGIUV), while experiencing its heyday. Until old age he was head of the department, he provide a great medical, scientific and pedagogical work. Under his guidance, the Department has published two volumes of scientific works. In 1964, Alexander Moiseevich released his most fundamental work - textbook "Operative urogynecology", which had undergone a large number of publications and is still very popular and respected. The book contained new methods of surgical treatment of these patients and were the results of his own 40-year experience and observations on surgical treatment of urogynecological patients at the Institute of Obstetrics and Gynecology, Academy of Medical Sciences of the USSR, in the departments of obstetrics and gynecology at Arkhangelsk State Medical Institute and Novokuznetsk GIUV. For this period were made more than 1,000 operations over the urogenital and rectal fistulas of different etiology, as well as the relative incontinence and tumors of the genitourinary system.

The chapter "About perforation pelvic abscesses in neighboring organs" was introduced in the book to help physicians involved in purulent surgery, as well-known surgeon V.F. Vojno-Yasenetsky (St. Luke) earlier in his book "Sketches of purulent surgery" proposed the idea of the creation of a new discipline - piologii, for a detailed study of the 
morphological, biological and physico-chemical properties of purulent infection, did not consider the question of the fate of pelvic abscesses, perforation into the bladder, rectum, and other organs.

Each operation over or that urogynecological disease was described in detail and step by step with the application of visual graphics, photos or radiographs schemes. All images, X-rays generally were original and were produced during practice of the author. Before describing the operations set out a brief history of the issue, the etiology and pathogenesis, diagnosis, and clinical course. The book traced the idea that engage in this activity should not only urologists, surgeons or obstetricians and gynecology with knowledge and practices in these adjoining areas, which see in the female pelvis one. A.M. Mazhbits wrote: "Obstetrics-gynecology and female urology are the daughter cells of general surgery, there are twins of different age limit, genetically, clinically and practically so intimately related to one another, that the boundaries between them are often smoothed out". At the present time the employees of the Museum Complex of the Northern State Medical University have been working on the study of the life and work of Professor Alexander Moiseevich Mazhbits, especially during the period of superintendence of the Department of Obstetrics and Gynecology of ASMI.

\section{Лumepamypa}

1. 21 ноября - 120 лет со дня рождения Александра Моисеевича Мажбица // Юбилейные и памятные даты медицины и здравоохранения Архангельской области на 2014 год. Архангельск, 2014. Т. 1.

2. Кира Е.Ф., Беженарь В. Ф., Кира К.Е., Безменко А. А., Пермяков А.С., Марьева Г.Г. Урогинекология в России: истоки развития и этапы становления // Журнал акушерства и женских болезней. 2011. № 1.

3. Мажбиц А. М. Бальнеотерапия в гинекологии и акушерстве: руководство для врачей. Л., 1947.

4. Мажбиц А. М. Библиография научных трудов Центрального института акушерства и гинекологии Министерства здравоохранения СССР за 150 лет (1797-1947). Л., 1947.

5. Мажбиц А. М. Гонорея женщин и ее осложнения. Л., 1968.

6. Мажбиц А. М. Об операциях по поводу мочеполовых свищей у 30 женщин // Тезисы докладов XX научной сессии АГМИ. Архангельск, 1956.

7. Мажбиц А. М. Оперативная урогинекология. Л., 1964.

8. Мажбиц А. М. Побочные явления со стороны тазовых органов при рентгенорадиотерапии рака женских половых органов // Тезисы докладов межобластного совещания медицинских работников районов Северо-Запада и XIV выездной научной сессии Государственного онкологического института им. П. А. Герцена. Архангельск, 1958.

9. Мажбии Александр Моисеевич (1895-1977) // Цвелев Ю.В., Айламазян Э.К., Беженарь В.Ф. Связь времен. Акушеры-гинекологи России за три столетия. СПб., 2010.

10. Мажбиц Александр Моисеевич // Чиж И.М. Военные врачи - участники Великой Отечественной войны 1941-1945 гг. Часть 2: М-Я. Краткий биографический справочник. СПб., 1996.

11. Профессор Мажбиц Александр Моисеевич: [некролог] // Акушерство и гинекология. 1977. № 7. 


\section{References}

1. November 21 - the 120th anniversary of the birth of Alexander Moiseevich Mazhibitz // Jubilee and memorable dates for medicine and health of the Arkhangelsk region for 2014. Arkhangelsk, 2014. Vol. 1.

2. Kira E.F., Bezhenar V.F., Kira K.E., Bezmenko A.A., Permyakov A.S., Maryeva G.G. Urogynecology in Russia: the origins of development and the stages of development // Journal of Obstetrics And female diseases. 2011. No 1.

3. Mazhbits A.M. Balneotherapy in gynecology and obstetrics: a guide for doctors. L., 1947.

4. Mazhbits A.M. Bibliography of scientific works of the Central Institute of Obstetrics and Gynecology of the Ministry of Health of the USSR for 150 years (1797-1947). L., 1947.

5. Mazhbits A.M. Gonorrhea of women and its complications. L., 1968.

6. Mazhbits A.M. About operations on urino-genital fistula in 30 women // Theses of the reports of the XXth scientific session of the AGMI. Arkhangelsk, 1956.

7. Mazhbits A.M. Operative urogynecology. L., 1964.

8. Mazhbits A.M. Side effects from the pelvic organs with X-ray-diotherapy of female genital cancer // Abstracts of reports of the interregional meeting of medical workers of the North-West and XIV visiting scientific session of the State Cancer Institute named after. P. A. Hercen. Arkhangelsk, 1958.

9. Mazhbits Alexander Moiseevich (1895-1977) // Tsvelev Yu.V., Eilamazyan E.K., Bezhanyar V.F. The connection of times. Obstetricians-gynecologists of Russia for three centuries. St. Petersburg., 2010.

10. Mazhbits Alexander Moiseevich // Chizh I.M. Military doctors - participants of the Great Patriotic War of 1941-1945. Part 2: A brief biographical reference. SPb., 1996.

11. Professor Mazhbits Alexander Moiseevich: [obituary] // Obstetrics and gynecology. 1977. No 7.

February, 21, 2017 